OPEN ACCESS

Edited by:

Karl Tsim,

Hong Kong University of Science and

Technology, Hong Kong

Reviewed by:

Guisheng Zhou,

Nanjing University of Chinese

Medicine, China

Zhi Rong Tan,

Central South University, China

*Correspondence:

Hongzhu Guo

guohz@bidc.org.cn

Min Ye

yemin@bjmu.edu.cn

Specialty section:

This article was submitted to

Ethnopharmacology,

a section of the journal

Frontiers in Pharmacology

Received: 02 November 2019 Accepted: 24 December 2019

Published: 21 February 2020

Citation:

Liu H, Ye M and Guo H (2020) An Updated Review of Randomized Clinical Trials Testing the Improvement of Cognitive Function of Ginkgo biloba

Extract in Healthy People and

Alzheimer's Patients.

Front. Pharmacol. 10:1688.

doi: 10.3389/fphar.2019.01688

\section{An Updated Review of Randomized Clinical Trials Testing the Improvement of Cognitive Function of Ginkgo biloba Extract in Healthy People and Alzheimer's Patients}

\author{
Haolong Liu ${ }^{1,2}$, Min $\mathrm{Ye}^{1 *}$ and Hongzhu Guo ${ }^{2 *}$ \\ 1 School of Pharmaceutical Sciences, Peking University, Beijing, China, ${ }^{2}$ Beijing Institute for Drug Control, NMPA Key \\ Laboratory for Quality Evaluation of Traditional Chinese Medicine (Traditional Chinese Patent Medicine), Beijing Key \\ Laboratory of Analysis and Evaluation on Chinese Medicine, Beijing, China
}

Alzheimer's disease (AD) is a common neurodegenerative disease, mainly manifested by cognitive dysfunction. It seriously reduces the quality of life, and there is no ideal treatment strategy in clinical practice. Clinical studies on the treatment of AD with Ginkgo biloba L. leaf extract (EGb) have been reported since 1980s, and many clinical studies have been carried out during the following 30 years. However, the benefits of EGb on the treatment of $A D$ are still controversial. In this review, we collected the clinical trial reports of EGb on cognitive function from Pubmed, Elsevier, Europe PMC, and other database since the 1980s. Through analysis and comparison, we consider that EGb may be able to improve the cognitive function in patients who suffered from mild dementia during long-term administration (more than 24 weeks) and appropriate dosage (240 mg per day). The main evidences and existing problems of the negative and positive experimental results were summarized.

Keywords: Ginkgo biloba L., Alzheimer's disease, cognitive function, clinical trials, EGb $761^{\circledR}$

\section{INTRODUCTION}

Alzheimer's disease (AD) is one of the age-related cognitive decline. It is a main challenge of mental health research (Tian et al., 2019), and is clinically characterized by cognitive dysfunction, neuronal injury, and synapse loss (Vanderstichele et al., 2019). Currently, there are approximately 50 million $\mathrm{AD}$ patients in the world (Bello-Medina et al., 2019). Although donepezil and memantine could delay $\mathrm{AD}$ symptom progression, side effects have been reported. Considering the number of $\mathrm{AD}$ patients and corresponding societal costs, plenty of clinical research has focused on the potential benefits of natural medicines.

Ginkgo biloba leaves are one of the popular herbal medicines, and they are recorded in the Chinese Pharmacopoeia (2015 edition). G. biloba leaves are well known in hypertension (AbdelZaher et al., 2018), ischemic myocardium (Zhang et al., 2016), and cerebral ischemia (Zhou et al., 2017). Remarkably, the extract of G. biloba leaves (EGb) attenuates the neuronal damage in animals (Li et al., 2017; Zhou et al., 2017) and in vitro (Yang et al., 2018). The chemical constituents of EGb 
are evaluated as follows: $22 \%-27 \%$ of flavone glycosides, $2.8 \%-$ $3.4 \%$ of Ginkgolide A, B, and C, $2.6 \%-3.2 \%$ of bilobalide, and less than 5 ppm of ginkgolic acid (Chávez-Morales et al., 2017). Modern pharmacological studies have shown that the combination of extract of $G$. biloba and donepezil may be beneficial in the treatment of $\mathrm{AD}$ in rat and mice (Stein et al., 2015; Zhang et al., 2019). Furthermore, Ginkgolide B, one of the major active ingredients in EGb, can inhibit the neurotoxicity induced by $\beta$-amyloid (Shi et al., 2009; Li et al., 2013; Kaur et al., 2015; Gill et al., 2017).

However, whether EGb improves cognitive function in clinical study is a controversial question. Although a few available largescale clinical trials suggest that EGb is relatively efficacious in delaying the progress of dementia, several other trials showed negative results. The present review searches large-scale clinical studies published in databases including Pubmed, ScienceDirect, and SpringerLink before 2019, and provides an analysis in the effective on cognitive function in EGb (Tables 1A, B).

\section{NEGATIVE CLINICAL RESULTS ON COGNITIVE FUNCTION}

\section{Single-Dose Studies}

A clinical study was conducted on the effect of EGb on cognitive function by Subhan in 1984 (Subhan and Hindmarch, 1984). Eight healthy female subjects were administered EGb or placebo, and the psychometric scale was tested after $1 \mathrm{~h}$ of administration. Only Sternberg technique was significantly improved with 600 mg EGb to placebo, and there was no difference in Critical Flicker Fusion test (CFF), Choice Reaction Time (CRT), and Leeds Analogue Rating Scales (LARS) among those groups. In 1985, Schaffler et al. (Schaffler and Reeh, 1985) showed EGb only improved complex choice reaction time in a clinical study.

Based on Subhan's research, Lacomblez et al. (1990) designed a clinical study in healthy young female volunteers in 1990. The volunteers received a single dose of EGb $(600 \mathrm{mg})$ or placebo, and a battery of tests were used after dosing. The results indicated that no statistical differences were observed on CFF and CRT. However, the long-term memory was improved with the followed treatment.

In 2002, Kennedy and Scholey collaborated on two clinical trials (Kennedy et al., 2002; Scholey and Kennedy, 2002). In Kennedy's research, 20 healthy young volunteers received ginkgo, ginseng, ginkgo combined with ginseng, and placebo, respectively. The Cognitive Drug Research (CDR) computerized assessment battery and cognitive outcome factors were used for evaluating cognitive function. For CDR battery, a statistical difference was only observed in immediate word recall, numeric working memory, delayed word recalls, and picture recognition reaction time at $6 \mathrm{~h}$ after administration. Furthermore, the quality of memory and serial $7 \mathrm{~s}$ responses was improved at $6 \mathrm{~h}$ after administration. However, other test items had no statistical difference between EGb group and placebo. In Scholey's research, the dosage of EGb was adjusted to 120, 240, and $360 \mathrm{mg}$. In Serial Threes Task, a statistical difference was only observed in EGb group at $4 \mathrm{~h}$ after administration. There was no effect on Serial Seven Task at any time point after oral administration.

\section{Long-Term Studies}

In 2001, 26 healthy young females and 24 healthy young males were enrolled in a 30-day clinical trial (Stough et al., 2001). Then the subjects were assessed on the neuropsychological tests. The tests included the Digit Symbol Substitution Test (DSST), Speed of Comprehension Test (SCT), Symbol Digit Modalities Test (SDMT), Digit Span; Trail Making Test (TMT), Rey Auditory Verbal Learning Test (AVLT), and Inspection Time (IT). The validated battery of tests was employed to evaluate attention, memory, and work performance. The results indicate that Digit Span Backwards, Working Memory Speed, and AVLT were improved in participants after administration, but the effect was not observed on any of the other tests.

In 2003, 214 participants were allocated to one of three treatments $(160 \mathrm{mg} /$ day of EGb, $240 \mathrm{mg} /$ day of EGb, and placebo) (Dongen et al., 2003). All the participants received EGb for 12 weeks, then randomly allocated for their Ginkgo treatment or placebo for another 12 weeks. The score for Syndrom Kurz Test (SKT) and Nürnberger Alters Alltagsaktivitäten (NAA; Nuremberg Gerontopsychological Rating Scale for Activities of Daily Living) were not statistically significant after 24 weeks.

In 2004, 20 females and 19 males were supplemented for 13 weeks with $240 \mathrm{mg}$ of EGb, then the alertness and chemosensory function was used to evaluate cognitive function (Mattes and Pawlik, 2004). The results showed that EGb could improve performance on the chemosensory, but was ineffective at taste and smell function. Quality control problems of the EGb tablets may result in ineffectiveness after administration.

In 2005, 52 university students were randomly divided into EGb and placebo group (Elsabagh et al., 2005). Another 40 students received EGb and placebo in long-term study. In both experiments, the performances were evaluated through sustained attention, episodic memory, executive function, and completed mood rating scales. Sustained attention and pattern recognition memory were improved after acute ginkgo treatment, but there were no effects on other tests. There were also no effects on any cognitive tests after 6-week treatment.

To determine the clinical efficacy of EGb in $\mathrm{AD}$, outpatients were supplemented for 26-week treatment with EGb or placebo (Schneider et al., 2005). Finally, 513 outpatients, including 270 females and 243 males, were randomized to receive $120 \mathrm{mg} /$ day of EGb or $240 \mathrm{mg} /$ day of EGb or placebo for 26 weeks. The changes of Alzheimer's Disease Assessment Scale-cognitive subscale (ADAS-cog) and Alzheimer's Disease Cooperative Study-Clinical Global Impression of Change (ADCS-CGIC) between baseline and week 26 were applied for evaluation strategy. There were no significant differences between groups, and the trial did not show efficacy of EGb.

In 2006, Burns et al. published the results of their clinical experiments, which was a 12-week study assessing effects of EGb on cognitive abilities in healthy young (mean age 30.4 years) or older (mean age 61.7 years) adults (Burns et al., 2010). The effect of EGb was evaluated by a series of tests, including cognitive abilities test, chronometric test, and subjective well-being. There were no statistically significant differences on any tests in young participants. 
TABLE 1A | The negative results of clinical trials of $A D$ with EGb.

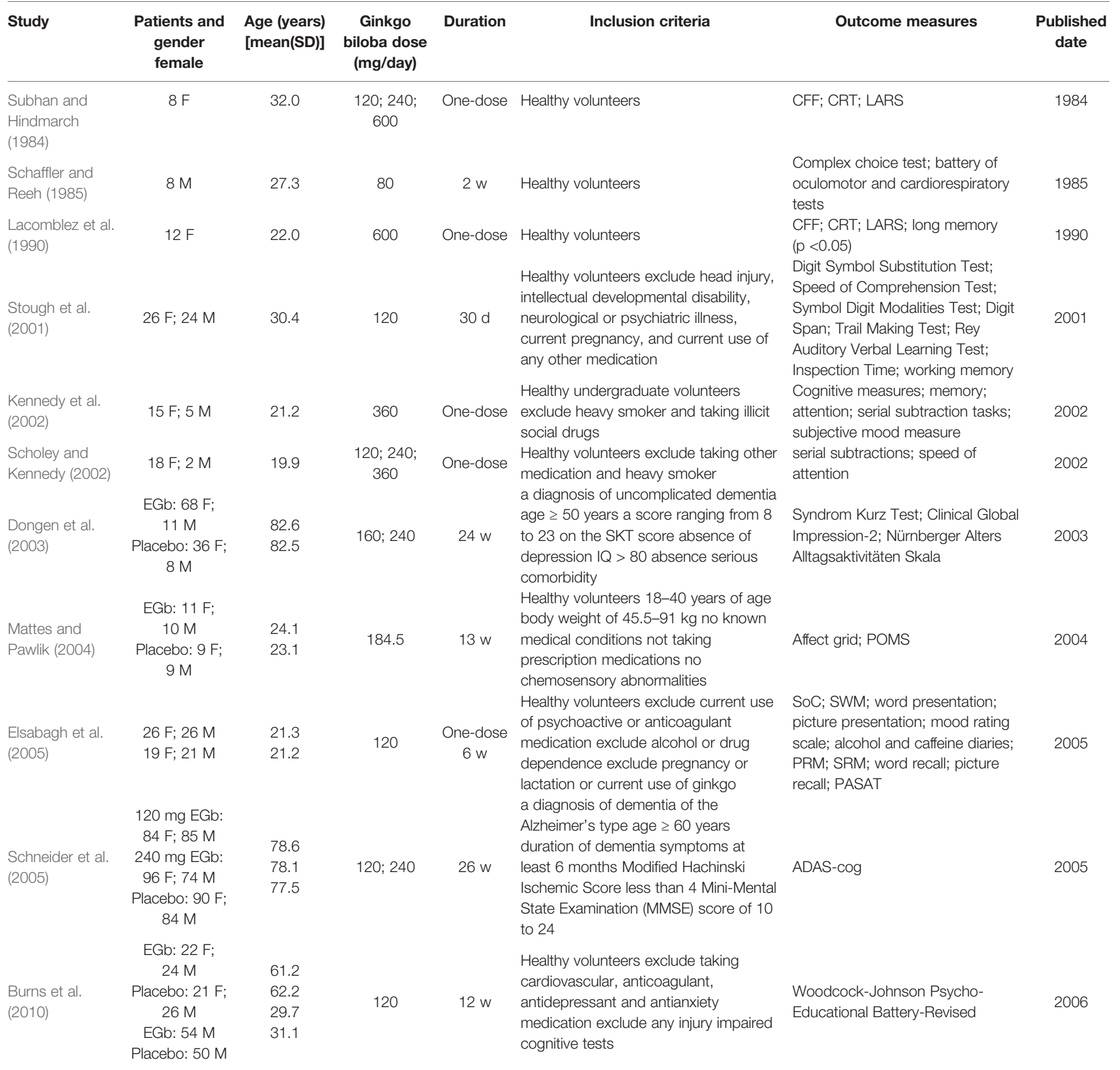

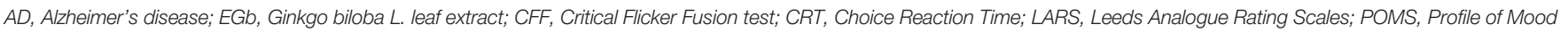

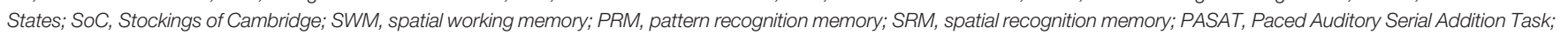
ADAS-cog, Alzheimer's Disease Assessment Scale.

\section{POSITIVE CLINICAL RESULTS ON COGNITIVE FUNCTION}

\section{Single-Dose Studies}

In 1999, Rigney et al. designed a clinic study to evaluate the effect of EGb (Rigney et al., 1999). Thirty-one health volunteers randomly received $120 \mathrm{mg}$ of EGb or $240 \mathrm{mg}$ of EGb or placebo. The battery of test consisted of Steinberg Short Term Memory (SSTM), Linear Analogue Rating Scale (LARS), Leeds
Sleep Evaluation Questionnaire (LSEQ), Scanning Task (STM), CFF, CRT, SCT, DSST, and Actigraphy. After administration of $\mathrm{EGb}$, there were statistically significant differences in reaction time, motor reaction time, and $\mathrm{CFF}$, and $\mathrm{EGb}$ were more pronounced for memory than attention.

In 2000, a study was designed to investigate the effects of acute doses of EGb on cognitive performance (Kennedy et al., 2000). Eighteen female and two male healthy college students (age 1924 years) received 120, 240, and $360 \mathrm{mg}$ of EGb or placebo. A 
TABLE 1B | The positive results of clinical trials of $A D$ with EGb.

\begin{tabular}{|c|c|c|c|c|c|c|c|}
\hline Study & $\begin{array}{l}\text { Patients } \\
\text { and gender } \\
\text { female }\end{array}$ & $\begin{array}{l}\text { Age (years) } \\
\text { [mean(SD)] }\end{array}$ & $\begin{array}{l}\text { Ginkgo } \\
\text { biloba dose } \\
\text { (mg/day) }\end{array}$ & Duration & Inclusion criteria & $\begin{array}{l}\text { Outcome measures } \\
\text { included in research }\end{array}$ & $\begin{array}{l}\text { Published } \\
\text { date }\end{array}$ \\
\hline $\begin{array}{l}\text { Wesnes et al. } \\
\text { (1987) }\end{array}$ & $\begin{array}{l}\text { EGb: } 8 \mathrm{~F} ; \\
19 \mathrm{M} \\
\text { Placebo: } \\
12 \mathrm{~F} ; 15 \mathrm{M}\end{array}$ & $\begin{array}{l}70.7 \\
71.3\end{array}$ & 120 & $\begin{array}{l}8 w \\
12 w\end{array}$ & $\begin{array}{l}\text { Elderly patients have mild signs of impairment } \\
\text { in everyday function on the Crichton Geriatric } \\
\text { Rating Scale }\end{array}$ & $\begin{array}{l}\text { Benton Visual Retention Test; } \\
\text { Digit Span Test; Psychometric } \\
\text { Test Battery }\end{array}$ & 1987 \\
\hline Rai et al. (1991) & $\begin{array}{l}\text { EGb: } 8 \mathrm{~F} ; \\
4 \mathrm{M} \\
\text { Placebo: } \\
12 \mathrm{~F} ; 3 \mathrm{M}\end{array}$ & $\begin{array}{l}73.4 \\
78.3\end{array}$ & 120 & $\begin{array}{l}12 w \\
24 w\end{array}$ & $\begin{array}{l}\text { Age } \geq 50 \text { years Have signs of mild to } \\
\text { moderate memory impairment classified by } \\
\text { NINCDS-ADRDA }\end{array}$ & $\begin{array}{l}\text { Folstein Mini-Mental State } \\
\text { Examination; Kendrick Battery } \\
(p<; 0.05) \text {; digit recall task } \\
(p<0.05)\end{array}$ & 1991 \\
\hline $\begin{array}{l}\text { Maurer et al. } \\
\text { (1997) }\end{array}$ & $\begin{array}{l}\text { EGb: } 5 \mathrm{~F} ; \\
4 \mathrm{M} \\
\text { Placebo: } 4 \mathrm{~F} ; \\
5 \mathrm{M}\end{array}$ & $\begin{array}{l}68.5 \\
60.6\end{array}$ & 240 & $12 w$ & $\begin{array}{l}\text { Age } 50-80 \text { years Hachinski Ischemic Score } \leq \\
4 \text { Mild to moderate Alzheimer-type senile } \\
\text { dementia Normal CT finding or a diffuse, } \\
\text { possibly asymmetric, atrophy }\end{array}$ & $\begin{array}{l}\text { SKT }(p<0.05) \text {; Trailmaking } \\
\text { test; ADCS }\end{array}$ & 1997 \\
\hline $\begin{array}{l}\text { Le Bars et al. } \\
\text { (1997) }\end{array}$ & $\begin{array}{l}\text { EGb: } 65 \mathrm{~F} ; \\
55 \mathrm{M} \\
\text { Placebo: } \\
72 \mathrm{~F} ; 44 \mathrm{M}\end{array}$ & 68 & 120 & $52 w$ & $\begin{array}{l}\text { Age } \geq 45 \text { years A diagnosis of uncomplicated } \\
\text { dementia Mini-Mental State Examination } \\
\text { score of } 9 \text { to } 26 \text { Global Deterioration Scale } \\
\text { score of } 3 \text { to } 6\end{array}$ & $\begin{array}{l}\text { ADAS-cog }(p<0.05) ; \text { GERRI } \\
(p<0.01)\end{array}$ & 1997 \\
\hline $\begin{array}{l}\text { Rigney et al. } \\
\text { (1999) }\end{array}$ & $14 \mathrm{~F} ; 22 \mathrm{M}$ & 43.6 & $\begin{array}{l}120 ; 150 \\
240 ; 300\end{array}$ & $2 d$ & $\begin{array}{l}\text { Asymptomatic volunteers Good physical and } \\
\text { mental health Free from concomitant } \\
\text { medication }\end{array}$ & $\begin{array}{l}\text { Short-term memory test } \\
(p<0.05) \text {; reaction times } \\
(p<0.05)\end{array}$ & 1999 \\
\hline $\begin{array}{l}\text { Kennedy et al. } \\
\text { (2000) }\end{array}$ & 18 F; 2 M & 19.9 & $\begin{array}{l}\text { 120; } 240 ; \\
360\end{array}$ & One-dose & $\begin{array}{l}\text { Health undergraduate volunteers Free from } \\
\text { medication }\end{array}$ & $\begin{array}{l}\text { Speed of attention }(p<0.05) \text {; } \\
\text { accuracy of attention; quality } \\
\text { of memory }(p<0.05) \text {; speed of } \\
\text { memory }(p<0.05)\end{array}$ & 2000 \\
\hline $\begin{array}{l}\text { Le Bars et al. } \\
\text { (2000) }\end{array}$ & $\begin{array}{l}\text { EGb: } 65 \mathrm{~F} ; \\
55 \mathrm{M} \\
\text { Placebo: } \\
72 \mathrm{~F} ; 44 \mathrm{M}\end{array}$ & 68 & 120 & $26 w$ & $\begin{array}{l}\text { Age } \geq 45 \text { years A diagnosis of uncomplicated } \\
\text { AD or multi-infarct dementia MMSE score of } \\
9 \text { to } 26 \text { Global Deterioration Scale score of } 3 \\
\text { to } 6\end{array}$ & $\begin{array}{l}\text { ADAS-cog }(p<0.05) ; \text { GERRI } \\
(p<0.01)\end{array}$ & 2000 \\
\hline $\begin{array}{l}\text { Napryeyenko } \\
\text { et al. (2007) }\end{array}$ & $\begin{array}{l}\text { EGb: } 143 \mathrm{~F} ; \\
55 \mathrm{M} \\
\text { Placebo: } \\
142 \mathrm{~F} ; 55 \mathrm{M}\end{array}$ & $\begin{array}{l}65 \\
63\end{array}$ & 240 & $22 w$ & $\begin{array}{l}\text { Age } \geq 50 \text { years SKT score of } 9 \text { to } 23 \text { MMSE } \\
\text { score of } 14 \text { to } 25 \text { ADAS-cog score of } 17 \text { to } \\
35\end{array}$ & $\begin{array}{l}N P I(p<0.01) ; \text { SKT }(p<0.01) \\
\text { GBS-ADL }(p<0.01) ; \text { HAMD } \\
(p<0.01)\end{array}$ & 2007 \\
\hline $\begin{array}{l}\text { Napryeyenko } \\
\text { et al. (2009) }\end{array}$ & $\begin{array}{l}\text { EGb: } 70 \mathrm{~F} ; \\
34 \mathrm{M} \\
\text { Placebo: } \\
78 \mathrm{~F} ; 32 \mathrm{M}\end{array}$ & $\begin{array}{l}66 \\
64\end{array}$ & 240 & $22 w$ & $\begin{array}{l}\text { Age } \geq 50 \text { years SKT score of } 9 \text { to } 23 \text { MMSE } \\
\text { score of } 14 \text { to } 25 \text { ADAS-cog score of } 17 \text { to } \\
35 \mathrm{NPI} \text { score of } 5 \text { to } 12\end{array}$ & $\begin{array}{l}\text { NPI }(p<0.01) ; \text { SKT }(p<0.01) \text {; } \\
\text { GBS }(p<0.01)\end{array}$ & 2009 \\
\hline Ihl et al. (2011) & $\begin{array}{l}\text { EGb: } 139 \mathrm{~F} ; \\
63 \mathrm{M} \\
\text { Placebo: } \\
133 \mathrm{~F} ; 69 \mathrm{M}\end{array}$ & 65 & 240 & $24 w$ & $\begin{array}{l}\text { Age } \geq 50 \text { years Cognitive score }<35 \text { SKT } \\
\text { score of } 9 \text { to } 23 \text { MMSE score of } 14 \text { to } 25 \\
\text { ADAS-cog score of } 17 \text { to } 35 \text { NPI score } \geq 5\end{array}$ & $\begin{array}{l}\text { NPI }(p<0.01) ; \text { SKT }(p<0.01) \\
\text { ADCS-CGIC }(p<0.01)\end{array}$ & 2011 \\
\hline $\begin{array}{l}\text { Herrschaft et al. } \\
\text { (2012) }\end{array}$ & $\begin{array}{l}\text { EGb: } 139 \mathrm{~F} ; \\
61 \mathrm{M} \\
\text { Placebo: } \\
140 \mathrm{~F} ; 62 \mathrm{M}\end{array}$ & $\begin{array}{l}65.1 \\
64.9\end{array}$ & 240 & $24 w$ & $\begin{array}{l}\text { Age } \geq 50 \text { years Cognitive score }<35 \text { SKT } \\
\text { score of } 9 \text { to } 23 \text { MMSE score of } 14 \text { to } 25 \\
\text { NPI score } \geq 6\end{array}$ & $\begin{array}{l}\text { NPI }(p<0.01) ; \text { SKT }(p<0.01) \\
\text { ADCS-CGIC }(p<0.01)\end{array}$ & 2012 \\
\hline Ihl et al. (2012) & $\begin{array}{l}\text { EGb: } 109 \mathrm{~F} ; \\
54 \mathrm{M} \\
\text { Placebo: } \\
111 \mathrm{~F} ; 59 \mathrm{M}\end{array}$ & $\begin{array}{l}64.9 \\
64.2\end{array}$ & 240 & $24 w$ & $\begin{array}{l}\text { Age } \geq 50 \text { years Total error score }<35 \text { SKT } \\
\text { score of } 9 \text { to } 23 \text { MMSE score of } 14 \text { to } 25 \\
\text { NPI score } \geq 5\end{array}$ & $\begin{array}{l}\text { NPI }(p<0.05) ; \text { SKT }(p<0.05) ; \\
\text { ADCS-CGIC }(p<0.01)\end{array}$ & 2012 \\
\hline
\end{tabular}


TABLE 1B | Continued

\begin{tabular}{|c|c|c|c|c|c|c|c|}
\hline Study & $\begin{array}{l}\text { Patients } \\
\text { and gender } \\
\text { female }\end{array}$ & $\begin{array}{l}\text { Age (years) } \\
\text { [mean(SD)] }\end{array}$ & $\begin{array}{l}\text { Ginkgo } \\
\text { biloba dose } \\
\text { (mg/day) }\end{array}$ & Duration & Inclusion criteria & $\begin{array}{l}\text { Outcome measures } \\
\text { included in research }\end{array}$ & $\begin{array}{l}\text { Published } \\
\text { date }\end{array}$ \\
\hline $\begin{array}{l}\text { Hoerr and Nacu } \\
\text { (2016) }\end{array}$ & $\begin{array}{l}\text { EGb: } 139 \mathrm{~F} ; \\
61 \mathrm{M} \\
\text { Placebo: } \\
140 \mathrm{~F} ; 62 \mathrm{M}\end{array}$ & $\begin{array}{l}65.1 \\
64.9\end{array}$ & 240 & $24 w$ & $\begin{array}{l}\text { Scored } \leq 35 \text { in the Test for the Early } \\
\text { Detection of Dementia with Differentiation } \\
\text { from Depression SKT score of } 9 \text { to } 23 \text { NPI } \\
\text { score } \geq 6\end{array}$ & $N P I(p<0.01) ;$ SKT $(p<0.01)$ & 2016 \\
\hline $\begin{array}{l}\text { Rapp et al. } \\
\text { (2018) }\end{array}$ & $\begin{array}{l}\text { EGb: } 69 \mathrm{~F} ; \\
24 \mathrm{M} \\
\text { Donepezil: } \\
69 \mathrm{~F} ; 28 \mathrm{M}\end{array}$ & $\begin{array}{l}84.4 \\
84.2\end{array}$ & 240 & $12 \mathrm{~m}$ & $\begin{array}{l}\text { Age } \geq 80 \text { years MMSE score of } 10 \text { to } 23 \\
\text { DemTect score } \leq 9 \text { Scheltens index } \geq 2 \\
\text { Fazekas score } \leq 2\end{array}$ & MMSE & 2019 \\
\hline
\end{tabular}

SKT, Syndrom Kurz Test; GERRI, Geriatric Evaluation by Relative's Rating Instrument; CGI, Clinical Global Impression; NAB, Nüberger Alters-Beobachtungsskala; GBS-ADL, GottfriesBråne-Steen activities-of-daily-living; NPI, Neuropsychiatric Inventory; HAMD, Hamilton Rating.

Scale for Depression; ADCS-CGIC, Alzheimer's Disease Cooperative Study-Clinical Global Impression of Change.

NINCDS-ADRDS, National Institute of Neurological and Communicative Disorders and Stroke-Alzheimer's Disease and Related Disorders Association; CT, computerized tomography.

tailored version of the CDR computerized assessment battery was used for measuring cognitive function as a consequence of ingestion of EGb of placebo. Compared with the placebo, cognitive function was improved in a number of assessment substances. It was noteworthy that a number of tests were performed dose-dependently after acute administration of EGb.

\section{Long-Term Studies}

In 1987, outpatients including 20 females and 34 males (mean age 71.3 years) received $120 \mathrm{mg}$ of EGb or placebo for 12 weeks (Wesnes et al., 1987). The test items included cognitive test buttery and automated psychometric test battery. The batteries comprised the following tests: the Benton Visual Retention Test, Immediate Word Recall, Number Matching Task, Rapid Visual Information Processing Task, CRT, DSST, and Word Recognition. To avoid the limitation and the one-sidedness of experimental results, all tests were combined and measured using two different techniques. The results indicated that EGb was superior to placebo in cognitive tests after administration for 12 weeks. The same results were repeated in another clinical trial in 1991 (Rai et al., 1991).

In 1997, nine females and nine males, aged 50-80 years and suffering from mild to moderate dementia of the Alzheimer type, were randomly divided into two groups. These patients were treated with a daily dose of $240 \mathrm{mg}$ EGb or placebo for 3 months (Maurer et al., 1997). The SKT scores, Trailmaking test (ZVT), and ADAS were used to investigate the effect of EGb on the improvement of cognitive function. Among them, there was a significant difference in SKT test between the EGb group and the placebo group, while there was no significant difference in the other two tests. The SKT was particularly sensitive to changes in mild and moderate dementia, but ADAS showed lower sensitivity than SKT. Furthermore, ADAS showed similar trend with SKT scores.

In 1997, Kanowski et al. also evaluated the efficacy of EGb in 156 outpatients who suffered from dementia of the Alzheimer type (Kanowski et al., 1996). Patients were evaluated by Clinical Global Impressions (CGI), SKT, and Nüberger AltersBeobachtungsskala (NAB), respectively. There were significantly differences between EGb and placebo.

Le Bars et al. published two trials of EGb for dementia in 1997 and 2000 (Le Bars et al., 1997; Le Bars et al., 2000). In 1997, 309 patients were enrolled in the study, and the primary outcome measures included ADAS-cog, Geriatric Evaluation by Relative's Rating Instrument (GERRI), and CGIC. For the ADAS-cog and GERRI, there was a significant change observed in EGb group at the end point, and no difference was demonstrated in the CGIC. The same results were repeated in 2000 .

Hoerr et al. reported the benefits of EGb in dementia of $\mathrm{AD}$ type in 2003, 2012, and 2016, respectively (Kanowski and Hoerr, 2003; Herrschaft et al., 2012; Hoerr and Nacu, 2016). In 2003, 205 patients were included in a trial, and the primary outcome measures were SKT, CGI, and NAB. The effects were statistically significant in SKT and CGI. The EGb showed a mild improvement of NAB in treatment group and placebo group, although there was no statistical difference between the groups. In 2012, the Neuropsychiatric Inventory (NPI) was added into the test item in order to investigate the benefit effect of EGb on neuropsychiatric symptoms (NPSs). The dosage of administration and course of treatment referred to the clinical trial in 2003. The results indicated that EGb alleviated NPSs in patients with dementia. The same results were repeated in another clinical trial in 2016.

In 2006, Mazza et al. designed a study to compare the therapeutic effect of EGb and donepezil in patients with $\mathrm{AD}$ (Mazza et al., 2006). The 76 patients were randomly divided into EGb group, donepezil group, and placebo group, respectively. Mini-Mental State Examination (MMSE), SKT, and CGI were important parameters in demonstrating the clinical efficacy of EGb in cognitive performance. Finally, EGb group and donepezil group showed a statistically significant difference compared with placebo. The results confirmed the efficacy of EGb in cognitive performance, comparable with donepezil clinical efficacy.

In 2007 and 2009, two large-scale clinical trials were designed to study the effect of EGb in cognitive performance by Napryeyenko (Napryeyenko and Borzenko, 2007; Napryeyenko et al., 2009). In 2007, 391 outpatients suffered from $A D$ or vascular dementia (VaD). The patients in EGb group received $240 \mathrm{mg} /$ day of EGb for 22 weeks. The NPI, SKT, and activities-of-daily-living subscale of Gottfries-Bråne-Steen (GBS-ADL) were used to evaluated the clinical efficacy of EGb, and there were significant differences in the test battery. The same results were repeated in 
another clinical trial in 2009, and EGb was safe and effective in the treatment of mild dementia caused by $\mathrm{AD}$ or $\mathrm{VaD}$.

In 2011 and 2012, Ihl published two clinical studies, which were used to confirm the therapeutic effects of EGb on cognitive dysfunction in elder patients suffered from AD (Ihl et al., 2011; Ihl et al., 2012). In both researches, more than 400 outpatients were randomly divided into two groups, which were allocated to receive EGb (240 mg/day) or placebo for 24 weeks. In the result, SKT and NPI scores were improved by EGb, all secondary outcome measures were also improved, including ADCSCGIC, Verbal Fluency Test, and Alzheimer's Disease Activities-of-Daily-Living International Scale (ADL-IS). Furthermore, adverse event rates were not increased in EGb group. Therefore, EGb was significantly superior to placebo in the treatment of dementia with NPSs.

Recently, Rapp compared treatment outcomes to provide the safety and efficacy of EGb (Rapp et al., 2018). The 189 patients were randomly treated with EGb (240 mg/day) or donepezil (5 or $10 \mathrm{mg} /$ day) for 12 months. There were no significant differences in cognitive decline measured with the MMSE over 12 months, and the last observation carried forward (LOCF) showed a mild favorable effect for EGb 761 over donepezil.

\section{DISCUSSION}

EGb has been used therapeutically for many years for symptoms such as cognitive decline, memory deterioration, and decreased alertness. In this review, we summarized the clinical studies from 1984 to 2018, aiming to evaluate the effects of EGb on the intervention of cognitive dysfunction. By comparing the above negative and positive results in Tables $\mathbf{1}$ and 2, we found several key factors that influenced the results.

\section{Course and Dosage of Administration}

Among the 12 negative results, the duration of administration was mostly single or short-term (less than 12 weeks), and only two experiments were conducted for long-term administration (more than 22 weeks). On the other hand, in the positive results, 11 studies were administered for longer than 22 weeks. In Ihl's and Napryeyenko's research, the changes of SKT score and NPI score were obviously observed in 12-week and 24-week. The differences between the EGb group and the placebo group were gradually expressed with the progress of treatment. Therefore, long-term study was more suitable to evaluate the therapeutic effect of EGb on cognitive dysfunction caused by AD.

Among the 11 negative results, $120 \mathrm{mg}$ or less EGb was administered to treat patients in seven studies. However, 10 positive studies allocated to the treatments with $240 \mathrm{mg}$ or more of EGb. Mattes got negative results, but found that the tablets contained only $65 \%$ of the expected concentration in re-analysis. Through literature review and analysis, Mattes found that the treatment can achieve better therapeutic effect when the dosage of EGb was more than $240 \mathrm{mg} /$ day. This opinion was also confirmed in Hashiguchi's research.
TABLE 2 | Consensus statements of EGb from the Asian Clinical Expert Group on Neurocognitive Disorders.

\begin{tabular}{|c|c|c|}
\hline No & $\begin{array}{l}\text { Consensus } \\
\text { statement }\end{array}$ & Concrete content \\
\hline 1 & $\begin{array}{l}\text { Efficacy of EGb } 761^{\circledR} \\
\text { in } A D, V a D \text {, and } \\
\text { BPSD }\end{array}$ & $\begin{array}{l}\text { Best practice for the pharmacological treatment as } \\
\text { follows: } \\
\text { AD: AChEl, memantine, EGb } \\
\text { VaD: AChEl, memantine, EGb, antiplatelet therapy } \\
\text { BPSD: ChEl, nonpharmacological treatment, } \\
\text { antipsychotics (off-label), memantine, SSRIs, } \\
\text { sedatives, and EGb }\end{array}$ \\
\hline 2 & Management of $\mathrm{MCl}$ & EGb may be considered for use in patients with $\mathrm{MCl}$ \\
\hline 3 & How to use EGb & $\begin{array}{l}\text { EGb can be used as a single agent, and allow } \\
\text { sufficient time to take effect }\end{array}$ \\
\hline 4 & The dosage & EGb at daily dose of $240 \mathrm{mg}$ \\
\hline 5 & $\begin{array}{l}\text { Lack of efficacy or } \\
\text { intolerance of } \\
\text { standard drugs may } \\
\text { warrant use of EGb }\end{array}$ & $\begin{array}{l}\text { EGb was recommended to treat } A D, V a D \text {, and } \\
\text { mixed dementia, when the patients unable to } \\
\text { tolerate the side effects of standard treatments }\end{array}$ \\
\hline 6 & Adjunctive therapies & $\begin{array}{l}\text { EGb was one of the key management options } \\
\text { adjunctive to standard pharmacological therapy for } \\
A D, V a D \text {, and BPSD }\end{array}$ \\
\hline 7 & $\begin{array}{l}\text { Management of } \\
\text { comorbidities }\end{array}$ & $\begin{array}{l}\text { EGb played an important role in the management of } \\
\text { co-morbidities, such as hypertension, in patients } \\
\text { with AD, VaD, and BPSD }\end{array}$ \\
\hline 8 & $\begin{array}{l}\text { Does not appear to } \\
\text { prevent dementia }\end{array}$ & $\begin{array}{l}\text { EGb was not recommended for prevention of } \\
\text { dementia }\end{array}$ \\
\hline 9 & Well tolerated & $\begin{array}{l}\text { EGb had a good tolerability profile in the treatment } \\
\text { of } M C l, A D, V a D \text {, and BPSD }\end{array}$ \\
\hline 10 & $\begin{array}{l}\text { No overall increased } \\
\text { bleeding risk }\end{array}$ & $\begin{array}{l}\text { EGb appeared to be no overall added risk of } \\
\text { bleeding }\end{array}$ \\
\hline 11 & $\begin{array}{l}\text { No significant } \\
\text { interaction with } \\
\text { anticoagulants or } \\
\text { antiplatelet agents }\end{array}$ & $\begin{array}{l}\text { EGb had been demonstrated no significant } \\
\text { interaction with anticoagulants and antiplatelet } \\
\text { agents }\end{array}$ \\
\hline
\end{tabular}

$A D$, Alzheimer's disease; VaD, vascular dementia; BPSD, behavioral and psychological symptoms of dementia; $\mathrm{MCl}$, mild cognitive impairment; $\mathrm{AChEl,}$ acetylcholinesterase inhibitors; SSRIs, Selective Serotonin Reuptake Inhibitors.

\section{Inclusion Criteria}

Through the analysis of negative and positive results, the inclusion criteria play a key role. In the negative studies, nine clinical studies involved healthy young subjects. However, 13 clinical studies involved elder outpatients in positive research. In the metaanalysis published by Lijuan Jiang (Jiang et al., 2013), EGb was more suitable for the treatment of elderly patients, especially aged 60 to 75 years. Furthermore, several studies have also set strict rules about the inclusion criteria, including the MMSE, SKT, and NPI score.

\section{Outcome Measures}

Through meta-analysis, Hyde thought that EGb was more suitable for the treatment of patients suffered from AD combined with mental disorder (Hyde et al., 2017). Hashiguchi further pointed out that SKT score was more applicable to evaluate patients with mild-moderate AD (Hashiguchi et al., 2015). During recent years, SKT score was used to evaluate the therapeutic effect in positive results.

In 2018, nine countries, including China, Germany, and Singapore, had jointly published a clinical guideline on the treatment of dementia mild cognitive impairment with EGb 
(Kandiah et al., 2019). In the guideline, several compelling evidences supported the inclusion of EGb as part of the treatment armamentarium for $\mathrm{AD}$ or $\mathrm{VaD}$ (Table 2). $\mathrm{EGb}$ showed encouraging efficacy in terms of improvement in cognition impairment and mental condition in patients with $\mathrm{AD}$ or $\mathrm{VaD}$.

Through analysis and comparison, we consider EGb may be able to improve the cognitive function in patients suffering from mild dementia during administration (more than 24 weeks) and appropriate dosage ( $240 \mathrm{mg}$ per day). However, there are some limitations in the studies that should be noted. $\mathrm{AD}$ is a disease with a long course; the effects of the drug may change over time. According to a recent research, aducanumab was deemed to indicate little chance of treatment efficacy in March 2019 (Howard and Liu, 2019), but the conclusion was overturned with the full 18 months of treatment in October 2019 (http:// investors.biogen.com/news-releases/news-release-details/ biogen-and-eisai-discontinue-phase-3-engage-and-emergetrials). In our opinion, most clinical trials of EGb were less than 24 weeks. We suggest that clinical trials with longer treatment are more appropriate to demonstrate the efficacy of EGb. Furthermore, some key biomarkers such as apolipoprotein E4

\section{REFERENCES}

Abdel-Zaher, A. O., Farghaly, H. S. M., El-Refaiy, A. E. M., and Abd-Eldayem, A. M. (2018). Protective effect of the standardized leaf extract of G inkgo biloba (EGb761) against hypertension-induced renal injury in rats. Clin. Exp. Hypertens. 9, 1-12. doi: 10.1080/10641963.2018.1425421

Bello-Medina, P. C., González-Franco, D. A., Vargas-Rodríguez, I., and DíazCintra, S. (2019). Oxidative stress, the immune response, synaptic plasticity, and cognition in transgenic models of Alzheimer disease. Neurologia. 19, 30109-30104. doi: 10.1016/j.nrl.2019.06.002

Belloy, M. E., Napolioni, V., and Greicius, M. D. (2019). A quarter century of APOE and alzheimer's disease: progress to date and the path forward. Neuron. 5, 820-838. doi: 10.1016/j.neuron.2019.01.056

Berg, C. N., Sinha, N., and Gluck, M. A. (2019). The Effects of APOE and ABCA7 on cognitive function and alzheimer's disease risk in african americans: a focused mini review. Front. Hum. Neurosci. 13, 387. doi: 10.3389/ fnhum.2019.00387

Burns, N. R., Bryan, J., and Nettelbeck, T. (2010). Ginkgo biloba: no robust effect on cognitive abilities or mood in healthy young or older adults. Hum. Psychopharmacol. 1, 27-37. doi: 10.1002/hup.739

Chávez-Morales, R. M., Jaramillo-Juárez, F., Rodríguez-Vázquez, M. L., MartínezSaldaña, M. C., Del Río, F. A. P., and Garfias-López, J. A. (2017). The Ginkgo biloba, extract $(\mathrm{GbE})$ protects the kidney from damage produced by a single and low dose of carbon tetrachloride in adult male rats. Exp. Toxicol. Pathol. 7, 430-434. doi: 10.1016/j.etp.2017.04.003

Dongen, M. V., Rossum, E. V., Kessels, A., Sielhorst, H., and Knipschild, P. (2003). Ginkgo for elderly people with dementia and age-associated memory impairment: a randomized clinical trial. J. Clin. Epidemiol. 4, 367-376. doi: 10.1016/s0895-4356(03)00003-9

Elsabagh, S., Hartley, D. E., Ali, O., Williamson, E. M., and File, S. E. (2005). Differential cognitive effects ofGinkgo bilobaafter acute and chronic treatment in healthy young volunteers. Psychopharmacol. (Berl). 2, 437-446. doi: 10.1007/ s00213-005-2206-6

Gill, I., Kaur, S., Kaur, N., Dhiman, M., and Mantha, A. K. (2017). Phytochemical Ginkgolide B Attenuates Amyloid- $\beta 1-42$ Induced Oxidative Damage and altered cellular responses in human neuroblastoma SH-SY5Y cells. J. Alzheimers Dis. 60 (s1), S25-S40. doi: 10.3233/JAD-161086

Hashiguchi, M., Ohta, Y., Shimizu, M., Maruyama, J., and Mochizuki, M. (2015). Meta-analysis of the efficacy and safety of Ginkgo biloba extract for the
(APOE4) were identified as a single greatest genetic risk factor for sporadic AD in clinical settings (Lin et al., 2018; Belloy et al., 2019; Berg et al., 2019). However, APOE4 was not involved in the study of EGb. Therefore, the relationship between EGb and APOE was still a mystery; it may be a research direction in the future.

\section{AUTHOR CONTRIBUTIONS}

HG conceived the study. HL acquired the data and drafted the manuscript. HG and MY revised the manuscript. All authors read and approved the final manuscript.

\section{FUNDING}

This study was supported by the Beijing Natural Science Foundation (No. 7194283) and the Beijing Postdoctoral Research Foundation (No. 2018-ZZ-069). treatment of dementia. J. Pharm. Health Care Sci. 1, 14. doi: 10.1186/ s40780-015-0014-7

Herrschaft, H., Nacu, A., Likhachev, S., Sholomov, I., Hoerr, R., and Schlaefke, S. (2012). Ginkgo biloba extract EGb $761^{\circledR}$ in dementia with neuropsychiatric features: a randomised, placebo-controlled trial to confirm the efficacy and safety of a daily dose of $240 \mathrm{mg}$. J. Psychiatr. Res. 6, 716-723. doi: 10.1016/ j.jpsychires.2012.03.003

Hoerr, R., and Nacu, A. (2016). Neuropsychiatric symptoms in dementia and the effects of Ginkgo biloba extract EGb $761{ }^{\circledR}$ treatment: additional results from a 24-week randomized, placebo-controlled trial. J. Clin. Trials. 8, 1-6. doi: 10.2147/oajct.s93531

Howard, R., and Liu, K. Y. (2019). Questions EMERGE as Biogen claims aducanumab turnaround. Nat. Rev. Neurol. doi: 10.1038/s41582-019-0295-9

Hyde, A. J., May, B. H., Dong, L., Feng, M., Liu, S., Guo, X., et al. (2017). Herbal medicine for management of the behavioural and psychological symptoms of dementia (BPSD): a systematic review and meta-analysis. J. Psychopharmacol. 2, 169-183. doi: 10.1177/0269881116675515

Ihl, R., Bachinskaya, N., Korczyn, A. D., Vakhapova, V., Tribanek, M., Hoerr, R., et al. (2011). Efficacy and safety of a once-daily formulation of Ginkgo biloba extract EGb 761 in dementia with neuropsychiatric features: a randomized controlled trial. Int. J. Geriatr. Psychiatry 11, 1186-1194. doi: 10.1002/gps.2662

Ihl, R., Tribanek, M., and Bachinskaya, N. (2012). Efficacy and tolerability of a once daily formulation of Ginkgo biloba Extract EGb $761^{\circledR}$ in alzheimer's disease and vascular dementia: results from a randomised controlled trial. Pharmacopsychiatry 2, 41-46. doi: 10.1055/s-0031-1291217

Jiang, L., Su, L., Cui, H., Ren, J., and Li, C. (2013). Ginkgo biloba extract for dementia: a systematic review. Shanghai Arch. Psychiatry 1, 10-21. doi: 10.3969/j.issn.1002-0829.2013.01.005

Kandiah, N., Ong, P., Yuda, T., Ng, L. L., Mamun, K., Merchant, R. A., et al. (2019). Treatment of dementia and mild cognitive impairment with or without cerebrovascular disease: expert consensus on the use of Ginkgo biloba extract, EGb $761^{\circledR}$. CNS Neurosci. Ther. 2, 288-298. doi: 10.1111/cns.13095

Kanowski, S., and Hoerr, R. (2003). Ginkgo biloba extract EGb 761 in dementia: intentto-treat analyses of a 24-week, multi-center, double-blind, placebo-controlled, randomized trial. Pharmacopsychiatry 36, 279-303. doi: 10.1055/s-2003-45117

Kanowski, S., Herrmann, W., Stephan, K., Wierich, W., and Hörr, R. (1996). Proof of efficacy of the ginkgo biloba special extract EGb 761 in outpatients suffering from mild to moderate primary degenerative dementia of the alzheimer type or multiinfarct dementia. Pharmacopsychiatry 2, 47-56. doi: 10.1055/s-2007-979544 
Kaur, N., Dhiman, M., Perez-Polo, J. R., and Mantha, A. K. (2015). Ginkgolide B revamps neuroprotective role of apurinic/apyrimidinic endonuclease 1 and mitochondrial oxidative phosphorylation against A $\beta 25-35$-induced neurotoxicity in human neuroblastoma cells. J. Neurosci. Res. 6, 938-947. doi: 10.1002/jnr.23565

Kennedy, D. O., Scholey, A. B., and Wesnes, K. A. (2000). The dose-dependent cognitive effects of acute administration ofGinkgo bilobato healthy young volunteers. Psychopharmacol. (Berl). 4, 416-423. doi: 10.1007/s002130000501

Kennedy, D. O., Scholey, A. B., and Wesnes, K. A. (2002). Modulation of cognition and mood following administration of single doses of Ginkgo biloba, ginseng, and a ginkgo/ginseng combination to healthy young adults. Physiol. Behav. 5, 739-751. doi: 10.1016/s0031-9384(02)00665-0

Lacomblez, L., Warot, D., Tarrade, T., and Puech, A. J. (1990). Psychopharmacological effects of Ginkgo Biloba extract (EGb 761) In healthy volunteers. Eur. J. Pharmacol. 4, 1460-1460. doi: 10.1016/0014-2999(90)94601-S

Le Bars, P. L., Katz, M. M., Berman, N., Itil, T. M., Freedman, A. M., and Schatzberg, A. F. (1997). A placebo-controlled, double-blind, randomized trial of an extract of ginkgo biloba for dementia. JAMA. 16, 1327-1332. doi: 10.1001/jama.278.16.1327

Le Bars, P. L., Kieser, M., and Itil, K. Z. (2000). A 26-week analysis of a doubleblind, placebo-controlled trial of the ginkgo biloba extract egb $761^{\circledR}$ in dementia. Dement. Geriatr. Cogn. Disord. 4, 230-237. doi: 10.1159/000017242

Li, L., Zhang, Q. G., Lai, L. Y., Wen, X. J., Zheng, T., Cheung, C. W., et al. (2013). Neuroprotective effect of ginkgolide B on bupivacaine-induced apoptosis in SH-SY5Y Cells. Oxid. Med. Cell Longev. 2013, 1-11. doi: 10.1155/2013/159864

Li, Z. Y., Chung, Y. H., Shin, E. J., Dang, D. K., Jeong, J. H., Ko, S. K., et al. (2017). YY-1224, a terpene trilactone-strengthenedGinkgo biloba, attenuates neurodegenerative changes induced by $\beta$-amyloid (1-42) or double transgenic overexpression of APP and PS1 via inhibition of cyclooxygenase2. J. Neuroinflammation 14, 94. doi: 10.1186/s12974-017-0866-X

Lin, Y. T., Seo, J., Gao, F., Feldman, H. M., Wen, H. L., Penney, J., et al. (2018). APOE4 causes widespread molecular and cellular alterations associated with alzheimer's disease phenotypes in human iPSC-derived brain cell types. Neuron 6, 1141-1154. doi: 10.1016/j.neuron.2018.05.008

Mattes, R. D., and Pawlik, M. K. (2004). Effects of Ginkgo biloba on alertness and chemosensory function in healthy adults. Hum. Psychopharmacol. 2, 81-90. doi: 10.1002/hup.562

Maurer, K., Ihl, R., Dierks, T., and Frölich, L. (1997). Clinical efficacy of Ginkgo biloba special extract EGb 761 in dementia of the Alzheimer type. J. Psychiatr. Res. 6, 645-655. doi: 10.1016/s0022-3956(97)00022-8

Mazza, M., Capuano, A., Bria, P., and Mazza, S. (2006). Ginkgo biloba and donepezil: a comparison in the treatment of Alzheimer's dementia in a randomized placebo-controlled double-blind study. Eur. J. Neurol. 9, 981985. doi: 10.1111/j.1468-1331.2006.01409.x

Napryeyenko, O., and Borzenko, I. (2007). Ginkgo biloba special extract in dementia with neuropsychiatric features. A randomised, placebo-controlled, double-blind clinical trial. Arzneimittelforschung. 1, 4-11. doi: 10.1055/s-00311296579

Napryeyenko, O., Sonnik, G., and Tartakovsky, I. (2009). Efficacy and tolerability of Ginkgo biloba extract EGb $761^{\circledR}$ by type of dementia: Analyses of a randomised controlled trial. J. Neurol. Sci. 1-2, 224-229. doi: 10.1016/ j.jns.2009.02.353

Rai, G. S., Shovlin, C., and Wesnes, K. A. (1991). A double-blind, placebo controlled study of Ginkgo biloba extract ('tanakan') in elderly outpatients with mild to moderate memory impairment. Curr. Med. Res. Opin. 6, 350-355. doi: 10.1185/03007999109111504

Rapp, M., Burkart, M., Kohlmann, T., and Bohlken, J. (2018). Similar treatment outcomes with Ginkgo biloba extract EGb 761 and donepezil in Alzheimer's dementia in very old age: a retrospective observational study. Int. J. Clin. Pharmacol. Ther. 3, 130-133. doi: 10.5414/CP203103

Rigney, U., Kimber, S., and Hindmarch, I. (1999). The effects of acute doses of standardized Ginkgo biloba extract on memory and psychomotor performance in volunteers. Phytother. Res. 5, 408-415.
Schaffler, K., and Reeh, P. W. (1985). Double blind study of the hypoxia protective effect of a standardized Ginkgo biloba preparation after repeated administration in healthy subjects. Arzneimittelforschung. 8, 1283.

Schneider, L. S., DeKosky, S. T., Farlow, M. R., Tariot, P. N., Hoerr, R., and Kieser, M. (2005). A randomized, double-blind, placebo-controlled trial of two doses of ginkgo biloba extract in dementia of the Alzheimer's type. Curr. Alzheimer. Res. 2, 541-551. doi: 10.2174/156720505774932287

Scholey, A. B., and Kennedy, D. O. (2002). Acute, dose-dependent cognitive effects of Ginkgo biloba, Panax ginseng and their combination in healthy young volunteers: differential interactions with cognitive demand. Hum. Psychopharmacol. 1, 35-44. doi: 10.1002/hup.352

Shi, C., Zhao, L., Zhu, B., Li, Q., Yew, D. T., Yao, Z., et al. (2009). Protective effects of Ginkgo biloba extract (EGb761) and its constituents quercetin and ginkgolide B against $\beta$-amyloid peptide-induced toxicity in SH-SY5Y cells. Chem. Biol. Interact. 1, 115-123. doi: 10.1016/j.cbi.2009.05.010

Stein, C., Hopfeld, J., Lau, H., and Klein, J. (2015). Effects of Ginkgo biloba Extract EGb 761, donepezil and their combination on central cholinergic function in aged rats. J. Pharm. Pharm. Sci. 4, 634-646. doi: 10.18433/j3wc8v

Stough, C., Clarke, J., Lloyd, J., and Nathan, P. J. (2001). Neuropsychological changes after 30-day Ginkgo biloba administration in healthy participants. Int. J. Neuropsychopharmacol. 4, 131-134. doi: 10.1017/S1461145701002292

Subhan, Z., and Hindmarch, I. (1984). The psychopharmacological effects of Ginkgo biloba extract in normal healthy volunteers. Int. J. Clin. Pharmacol. Res. 2, 89-93. doi: $10.1063 / 1.1707981$

Tian, J., Shi, J., Wei, M., Ni, J., Fang, Z., Gao, J., et al. (2019). Chinese herbal medicine Qinggongshoutao for the treatment of amnestic mild cognitive impairment: A 52-week randomized controlled trial. Alzheimers Dement. (N Y). 5, 441-449. doi: 10.1016/j.trci.2019.03.001

Vanderstichele, H. M., Teunissen, C. E., and Vanmechelen, E. (2019). Critical steps to be taken into consideration before quantification of $\beta$-amyloid and tau isoforms in blood can be implemented in a clinical environment. Neurol. Ther. 8 (Suppl 2), 129-145. doi: 10.1007/s40120-019-00166-3

Wesnes, K., Simmons, D., Rook, M., and Simpson, P. (1987). A double-blind placebocontrolled trial of tanakan in the treatment of idiopathic cognitive impairment in the elderly. Hum. Psychopharmacol. 3, 159-169. doi: 10.1002/hup.470020305

Yang, X., Zheng, T., Hong, H., Cai, N., Zhou, X., Sun, C., et al. (2018). Neuroprotective effects of Ginkgo biloba extract and Ginkgolide B against oxygen-glucose deprivation/reoxygenation and glucose injury in a new in vitro multicellular network model. Front. Med. 3, 307-318. doi: 10.1007/s11684-017-0547-2

Zhang, C., Wang, D. F., Zhang, Z., Han, D., and Yang, K. (2016). EGb 761 protects cardiac microvascular endothelial cells against hypoxia/reoxygenation injury and exerts inhibitory effect on the ATM pathway. J. Microbiol. Biotechnol. 3, 584-590. doi: 10.4014/jmb.1611.11024

Zhang, J., Wang, J., Zhou, G. S., Tan, Y. J., Tao, H. J., Chen, J. Q., et al. (2019). Studies of the anti-amnesic effects and mechanisms of single and combined use of donepezil and ginkgo ketoester tablet on scopolamine-induced memory impairment in mice. Oxid. Med. Cell Longev. 2019, 8636835. doi: 10.1155/ 2019/8636835

Zhou, X., Qi, Y., and Chen, T. (2017). Long-term pre-treatment of antioxidant Ginkgo biloba extract EGb-761 attenuates cerebral-ischemia-induced neuronal damage in aged mice. Biomed. Pharmacother. 85, 256-263. doi: 10.1016/ j.biopha.2016.11.013

Conflict of Interest: The authors declare that the research was conducted in the absence of any commercial or financial relationships that could be construed as a potential conflict of interest.

Copyright (c) $2020 \mathrm{Liu}, \mathrm{Ye}$ and Guo. This is an open-access article distributed under the terms of the Creative Commons Attribution License (CC BY). The use, distribution or reproduction in other forums is permitted, provided the original author(s) and the copyright owner(s) are credited and that the original publication in this journal is cited, in accordance with accepted academic practice. No use, distribution or reproduction is permitted which does not comply with these terms. 